Meta

Journal des traducteurs

Translators' Journal

\title{
Dwarfs in Giants' Lands: Some Observations on Translating Minor Literatures into High-Impact Cultures - The Case of Slovene Literature in Italy
}

\section{Martina Ožbot}

Volume 56, numéro 3, septembre 2011

URI : https://id.erudit.org/iderudit/1008330ar

DOI : https://doi.org/10.7202/1008330ar

Aller au sommaire du numéro

Éditeur(s)

Les Presses de l’Université de Montréal

ISSN

0026-0452 (imprimé)

1492-1421 (numérique)

Découvrir la revue

Citer cet article

Ožbot, M. (2011). Dwarfs in Giants’ Lands: Some Observations on Translating Minor Literatures into High-Impact Cultures - The Case of Slovene Literature in Italy. Meta, 56(3), 511-525. https://doi.org/10.7202/1008330ar
Résumé de l'article

Le présent article aborde la question de la traduction de la littérature appartenant à des langues et à des cultures mineures dans les langues des cultures majeures, en mettant l'accent sur le cas de la littérature slovène en Italie qui, d'ailleurs, présente beaucoup de points communs avec d'autres cas de rapports culturels asymétriques. L'objectif de l'article est de caractériser les facteurs qui contribuent à la réussite ou à l'échec de l'intégration dans la culture majeure de la littérature traduite de la langue mineure. Nous identifions et étudions quatre facteurs : a) l'environnement culturel et social de la langue cible ; b) les particularités littéraires, y compris le genre, du texte source ainsi que les critères de sélection des textes à traduire ; c) les compétences du traducteur; d) les stratégies de traduction utilisées. Nous concluons que la stratégie de traduction systématiquement orientée vers la langue cible est le facteur clé qui contribue à la réception réussie d’une littérature mineure au sein d'une culture cible majeure. 


\title{
Dwarfs in Giants' Lands: Some Observations on Translating Minor Literatures into High-Impact Cultures - The Case of Slovene Literature in Italy
}

\author{
MARTINA OŽBOT \\ University of Ljubljana, Ljubljana, Slovenia \\ martina.ozbot@guest.arnes.si
}

\begin{abstract}
RÉSUMÉ
Le présent article aborde la question de la traduction de la littérature appartenant à des langues et à des cultures mineures dans les langues des cultures majeures, en mettant l'accent sur le cas de la littérature slovène en Italie qui, d'ailleurs, présente beaucoup de points communs avec d'autres cas de rapports culturels asymétriques. L'objectif de l'article est de caractériser les facteurs qui contribuent à la réussite ou à l'échec de l'intégration dans la culture majeure de la littérature traduite de la langue mineure. Nous identifions et étudions quatre facteurs: a) l'environnement culturel et social de la langue cible; b) les particularités littéraires, y compris le genre, du texte source ainsi que les critères de sélection des textes à traduire; c) les compétences du traducteur; d) les stratégies de traduction utilisées. Nous concluons que la stratégie de traduction systématiquement orientée vers la langue cible est le facteur clé qui contribue à la réception réussie d'une littérature mineure au sein d'une culture cible majeure.
\end{abstract}

\begin{abstract}
The paper deals with questions related to the translation of literatures written in limiteddiffusion languages and belonging to low-impact cultures into languages of high-impact cultures. The analysis is centred on the introduction and presence of Slovene literature in contemporary Italy, although the Italian situation shares a great deal of similarity with other situations of asymmetrical translational transfer. In an attempt to identify the elements playing a role in the successful integration of a peripheral literature in a highimpact target culture, four factors are postulated and discussed: a) target extra-textual setting, b) literary and genre-related properties of source texts and criteria for their selection, c) translator's competence, d) translation strategies employed. It is suggested that a consistently target-oriented approach is central to a positive reception of a peripheral literature in a high-impact target setting.
\end{abstract}

\section{MOTS-CLÉS/KEYWORDS}

asymétries culturelles, traduction littéraire, naturalisation / exotisation, orientation cible cultural asymmetries, literary translation, domestication / foreignization, target orientation

\section{Preliminary remarks: researching the margins}

As is well known, over the past decades literary, linguistic and cultural studies have been developing an increasing interest in topics which were traditionally considered peripheral. Examples of such formerly peripheral areas of research which have become more mainstream are, for example, post-colonial literatures, texts written in dialects and those written in other non-standard language varieties. Probably translation, whether literary or non-literary, as a derived and therefore typically perceived 
as a less important and less prestigious activity than original writing is another case in point. This paper will address yet another peripheral issue, i.e., the problem of exportation, by means of translation, of literatures written in limited-diffusion languages and belonging to low-impact cultures into major languages and into highimpact cultures.

It is likely that literatures written in lesser-used European languages are now being translated into other languages with greater intensity than ever before. This can to an extent be accounted for by the new political situation in Europe, which, at least in certain respects, is becoming a process of integration, where more and more often voices from the periphery can be heard as well. In spite of this, various kinds of imbalances and asymmetries unavoidably persist - in terms of the self-sufficiency of cultures, of their interest in one another and in terms of the exchange between them. Relations of power do matter and keep on shaping literary and cultural maps. In this contribution I will attempt to shed light on problems related to situations when literatures from the margins are introduced into high-impact cultures and enter into interaction with canonical literatures. The analysis will be centred on the introduction and presence of Slovene literature in contemporary Italy (2008), although the Italian situation shares a great deal of similarity with other situations in which Slovene literature is exported, via translation, into other high-impact cultures. Also, by analyzing the characteristics of this particular case of translational exchange, general features will be pointed out which are applicable to other instances of asymmetrical cultural and translational transfer. Before examining the case in question, it needs to be emphasized that the translation of literary texts from minor literatures to high-impact cultures follows its own paths and differs in important ways both from the translational exchange between two high-impact cultures (for example, English and French) as well as from the translational exchange between two lowimpact cultures (for example, Slovene and Norwegian or Czech and Finnish), for in either situation the interest between the cultures involved is reciprocal. ${ }^{1}$

\section{2. (Un)interested neighbours: Italian and Slovene literatures}

Italian and Slovene cultures are neighbours and as such they have been in very close contact for centuries, in economic, political and cultural terms. However, in the area of culture, and of literature in particular, the exchange has mainly been unidirectional: Italian texts have been translated into Slovene since as early as the $16^{\text {th }}$ century (Brecelj 2000), many of them, like Dante's Divina Commedia, several times (Brecelj 1965; Škerlj and Rakar 1965) - which is not insignificant, given that there are at present only about 2.3 million Slovene speakers in the world; on the other hand, relatively few works of Slovene literature have found their way into Italian culture and only a couple of them have elicited considerable response in it. This is not surprising considering the status of Italian literature as a canon-forming literature with respect to which Slovene literature is peripheral. Such unequal relationships are a fact of life for all peripheral literatures - for example, literatures in limited-diffusion languages, literatures written in minority languages, postcolonial literatures. Of course, a separate discussion would be necessary to determine exactly what constitutes a canonical and what a peripheral literature. For our purposes, suffice to say that among the determining factors are the strength of the literary tradition, the political status of 
the language in which a given literature is written, and the number of speakers of that language, including its bi- or multilingual speakers, who are a precondition for translation to take place.

A look at some quantitative data reveals the following: in the period after World War II about 230 books and many more texts in various anthologies (around 50, comprising either exclusively texts by Slovene authors or texts by authors of other literatures as well, as is often the case with thematic anthologies), periodicals and other publications have been translated from Slovene into Italian (Jan 2001b). In these translations, one finds, apart from poetry as the most frequently translated genre (about 100 books, i.e., $43.5 \%$ of all the translations), also prose texts (about 55 books, i.e., 24\%), plays (about 15 books, i.e., 6,5\%), folk tales and texts for children (about 60 books, i.e., 26\%). Poetry represents an especially high proportion of the total amount of translation, in particular if one takes into account that besides single-author books of poetry, to which the 100 units refer, there are also multi-authored anthologies. The translated poets include classics, traditional and modern - some having been translated more than once - and apart from classics, there are numerous other authors, some of whom are mainly of local interest by virtue of being members of the Slovene minority in Italy $^{2}$ and at the same time of a mixed Italian-Slovene ethnicity. ${ }^{3}$ Although the figures are rather modest - especially since nowadays over 30.000 book titles are published in Italy per year - and although many of the translated writers did not receive a great deal of attention from Italian critics and / or readers, it remains true that Slovene literature is one of the Slavic literatures most frequently translated into Italian, second only to Russian literature. This is a notable achievement for one of Europe's smallest nations.

By way of comparison, let me add that in the same period about 800 books comprising Italian literary texts were translated into Slovene, most of which have attracted considerable attention from critics and / or readers. ${ }^{4}$ The disproportion in the amount of translation between the two literatures is understandable, as is the very small portion occupied by the Italian translations of Slovene literary texts in the total amount of literary translations into Italian (less than $0.5 \%$ ). Evidently, on a purely quantitative level, the total number of Slovene literary texts at any time is small compared to the total volume of texts from world literature which could potentially be translated into Italian. In addition, translation from other languages has historically played a much more important role in the development of Slovene literature, as a peripheral literature, than in the case of a canonical literature such as Italian, and, moreover, the demand for translations from peripheral literatures has on the whole been particularly low in Italy. What does seem to call for analysis and explanation is that in spite of considerable efforts made by individuals and by institutions to make Slovene writers known to Italian audiences, the results achieved have in many cases been rather modest, as is clear if the reception of Slovene literature in Italy is examined in terms of its geographical extension (local / regional / national), in terms of its presence in the media (reviews in different periodicals, on the radio, and on TV) and in terms of presentations at literary festivals and in other kinds of public readings: often the reception was geographically limited, had rather shallow media coverage and only lasted for a short period.

In what follows I shall try to offer an explanation for such a situation, taking into account different textual and extra-textual factors which have been identified as 
determining the potential of a peripheral translated literature to be successfully integrated in a high-impact cultural context. These factors are:

1) the target extra-textual setting;

2) literary and genre-related properties of source texts and criteria for their selection;

3) translator's competence;

4) the translation strategies employed.

However, before entering into a discussion of them, it is necessary to point out that on several occasions translations of Slovene literature have been very successful, in Italy and in other countries with canonical literatures. Let us have a quick look at some such examples.

\subsection{Success stories}

Among the authors who have been well received are, for instance, the fin-de-siècle writer Ivan Cankar (1876-1918) in Italy, modernist author Vladimir Bartol (19031967) in France, Italy, and Spain, as well as contemporary writers Boris Pahor (b. 1913) and Lojze Kovačič (1928-2004), the former being particularly successful in France, Austria, and Germany and since 2008 also in Italy, ${ }^{5}$ and the latter in Austria and Germany. Cankar's chief success was Hlapec Jernej in njegova pravica (The bailiff Jernej and his rights), ${ }^{6}$ a story revolving around the issue of property, class, and social justice, whereas Bartol became established with his pseudo-historical novel Alamut set in the Arab world. ${ }^{7}$ Pahor, one of the most frequently translated Slovene authors today, became known first by the numerous French and German translations of his partially autobiographical novels (in particular Nekropola), ${ }^{8}$ which take as a starting point the author's concentration-camp experiences during World War II. Kovačič has been highly acclaimed in Austria and Germany after a translation was published in 2004 of the first part of his autobiographical novel Prišleki (The Newcomers), ${ }^{9}$ a saga about his growing-up in Switzerland and the family's forced move to their father's homeland in the late 1930s.

Two conclusions can be drawn at this point. First, in all the cases mentioned above, it appears that the successful reception was made possible not only because of high-quality translations, but also the authors' potential to offer the target reader literary experiences which tie in well with his / her immediate interests shaped either by literary or extra-literary circumstances. For instance, in a period when the tenets of capitalist societies came to be questioned more and more intensely, Cankar's story, with its perceived allusions to the class struggle, appeared topical to the Italian reader, and, likewise, at a time characterized by a growing fear of Islamic fundamentalism, Bartol could hardly be more modern. Pahor's and Kovačič's texts are partially set in the French and in the German-speaking world respectively, which may to an extent explain the success of their translations in the two countries; apart from that, Pahor's favourable reception in France may also have been enhanced by the traditional interest of the French readers in resistance literature. Many other elements may certainly have been decisive for the reception of these texts, but it appears that a translation can only be successful in a target culture if it has a sufficient degree of communicative potential for the target reader - which may not match the status of the source text in the source literature - or, in other words, if there is enough common ground shared by the literary work as presented through the target text on the one hand and by the 
target reader on the other to allow a productive communicative exchange between them. It is clear, however, that the common ground constitutes merely a necessary and not a sufficient condition for a favourable reception, which may explain, for example, why the majority of the Slovene writers from Trieste have hardly had any success in Italy, although their texts are concerned with a reality, which is in many cases genuinely Italian. It seems that limited communication between the two ethnic groups of the city has also had important consequences for the exchange between the two literatures: the works of Slovene writers from Trieste have remained, until recently, virtually unknown to Italian readers, in spite of the translations of some of them being available on the Italian market, whereas the Italian Triestine authors, including Italo Svevo, Scipio Slataper and Umberto Saba, who are now considered canonical authors of Italian literature, only began to be translated into Slovene at the end of the 1980s, some notable exceptions being the translations of a novel by Svevo published in 1961 and of several poems by Saba scattered mainly in periodicals from the 1940s on. This, however, is not due merely to a lack of interest in the Triestine literature, but also to objective circumstances such as the limited number of literary translators from Italian into Slovene and the preferences shown by some of the key translation agents (translators, poets, publishers) since the 1960s for the translation of the older classics of Italian literature on the one hand and of more contemporary authors on the other.

Second, all the texts mentioned are prose texts. Although more books of Slovene poetry than other literary genres have been translated, at least into Italian, their reception was on the whole weaker. As a genre, poetry is likely to present more problems than other kinds of literary texts: in Slovene literature, the production of poetry in quantitative terms is very high compared to both prose and drama, and there may be cases when a book of poems is translated only because of the author's own desire to make his work available to a foreign audience. Often, however, such translation projects cannot be very far-reaching. Apart from this, poetry is inherently a difficult genre and tends to have fewer readers, for, in principle, it may presuppose greater effort and more cooperation from the reader than a short story or a novel. With some simplification, the observation could be ventured that poetry is written by many and read by few.

\subsection{Two exceptions which prove the rule}

Again, however, there are two Slovene authors who have had substantially more resonance in Italy than others: Ciril Zlobec and Srečko Kosovel. Let us have a glance at how they came on to the Italian literary scene.

Ciril Zlobec, who was born in 1925 in the Carso / Kras region, which straddles the Italian-Slovene border, and who is one of the foremost Slovene authors after World War II as well as an active translator from Italian and an important mediator between the two cultures, is probably the most successful of all Slovene writers translated into Italian. In his poetry, influences by Italian authors such as Ungaretti, Montale, and Quasimodo can be found. In the period between 1982 and 2004, five collections of Zlobec's poems in Italian translation were produced, ${ }^{10}$ all by Italian publishers, and his poetry is also represented in numerous anthologies. In general, the critical response has been quite strong. The majority of the texts were first translated by 
Zlobec himself and then refined by various Italian translators, among whom one can also find poets such as Giacinto Spagnoletti, Luciano Morandini, Ubaldino Sampaoli, Giacomo Scotti, Dante Maffia, Luciano Luisi and others. The translations of his texts are normally highly domesticating and function naturally as pieces of Italian literature (Ožbot 2000: 84-87; Ožbot 2001b: 302), which is at least partly due to the fact that nearly all the translators had no knowledge of the source language, which, consequently, enabled them to work relatively freely on the target texts to which they tried to give a poetically convincing expression in Italian, necessarily erasing any trace of linguistic specificity of the source texts.

Srečko Kosovel (1904-1926) was also born in the Carso / Kras region and had strong connections with the Triestine culture of the time (Jan 2004). Like Zlobec's works, several of Kosovel's poems also share characteristics with Italian literature, particularly with authors of Futurist orientation. During a thirty-year span beginning in 1972, nine books of his poetry were published in Italian and his texts have also appeared in various anthologies. ${ }^{11}$ In general, the translations are again of a domesticating nature, but not all the collections were produced in Italy, nor by well-known poets / translators or publishers. ${ }^{12}$ Nonetheless, Kosovel is the only Slovene author whose poems have been included in some Italian textbooks used in the schools of the region Friuli-Venezia Giulia (Jan 2001a: 38).

\section{The four factors}

After having discussed some representative examples of translated texts of a minor literature in high-impact cultural settings, we can now return to the four factors postulated above and examine them in some detail.

\subsection{Target extra-textual setting}

In relation to the extra-textual setting - which includes elements such as publishers, editors, authors of introductions, reviews and other responses in the media - it is to be noted that in the case of Slovene literature in Italian translation rather few books were produced by publishers which have high press-runs and distribute their products at a national level. What is more, some of them were even published in Slovenia, which, paradigmatically, seems to make success in the Italian market almost impossible to achieve, no matter how acceptable a translation as such may be for the target readers. Often, the accompanying texts were written by Slovene literary critics who were usually unknown in the target culture and whose forewords, introductions and notes did not take into account the specific interests and needs of the Italian reader. The above mentioned cases of success are exceptions which prove the rule: Pahor's much acclaimed Necropoli and Zlobec's collections of poems have been published in Italy, mainly by publishers whose books are distributed on a national scale; they were produced by expert translators - and, if necessary, also revised by language consultants - who were native speakers of Italian and with whom the authors could cooperate during the translation process; and also, the books are frequently introduced by important figures of Italian culture: one of Zlobec's collections of poems has a foreword by Giacinto Spagnoletti, a foremost literary critic, whereas in the new edition of Necropoli there is an introduction by Claudio Magris, an internationally recognized Triestine writer and a renowned intellectual. 


\subsection{Literary and genre-related properties of the source texts}

With respect to the literary and genre-related properties of the source texts and the criteria for their selection, one can observe that texts of various genres have been translated and that poetry occupies an extremely important position. The problem is, however, that the selection criteria were mainly based upon source-culture considerations, so that, again, the expected literary horizons and interests of target readers were often not taken into account. What enjoys a high status within the source literary system is often - and not only in the case of Slovene literature, of course - automatically expected to be of interest to a foreign audience as well. A typical example is the poetry of France Prešeren, the national poet, whose contribution to the development of the Slovene language and of Slovene literature has been very important indeed. Prešeren (1800-1849) introduced into Slovene literature not only the Romantic sensitivity but also a number of formal poetic models, and fully developed some verse forms, like the sonnet, which had only been used to a very limited extent by earlier Slovene authors. His poetry has been translated into Italian, ${ }^{13}$ as well as into a number of other languages, and into several of them more than once. ${ }^{14}$ The fundamental question is: have such large-scale translation projects been sensible at all, at least as far as the Italian readership is concerned? Italian literature had a considerable textual output in the Romantic period and one wonders whether there is any point in offering the Italian reader yet another Romantic poet (Novak 2001: 20). If so, then the translation should be carefully planned, at the extra-textual and at the textual levels. For the latter, it appears that chances of successful reception are greater if the translation is integrated into the target literary system, which can only be achieved through the translator's choices, hence the target text will become linguistically and culturally contextualized. The Italian reader has at his disposal a corpus of texts and it is important with which of them and in what ways the target text will resonate, either by drawing on them and adopting their lexical, syntactic, rhetorical or other elements or by distancing itself from them and thus referring to them per negationem.

A frequent problem with non-canonical literatures as source literatures is that the interest in the translation comes from the source culture itself and that a translation is made to satisfy the source-culture need for finding its way among foreign audiences, whereas in the case of translating canonical literatures the interest normally originates in the target literature. This makes the reception by target readers more likely to be successful, for the implication is that there is not only a possibility for translation, but also a necessity for it (Benjamin 2002: 109-110).

\subsection{Translator's competence}

At this point the translator's competence comes into play. Needless to say, for a translation to be appropriate in a given target-culture setting, the translator needs a wide range of knowledge and skills, including mastery of the source and target languages, knowledge of the source and target cultures and their literary traditions as well as a specific ability to translate between languages and cultures. But the translator's competence is merely a necessary and not a sufficient condition for the translation to be successful. To produce texts which will be convincing at a poetic level, for example, 
the translator needs much more, i.e., an ability to recreate the poetry of the original in the target language. Again, a look at Slovene texts in Italian translations shows that the majority of them are by Slovene translators who are bilingual speakers of Slovene and Italian or sometimes by Italian speakers who did not know the source language well enough to translate directly on the basis of the source texts (in certain cases, they may have no knowledge of the source language at all) and were therefore helped by bilingual speakers, who were sometimes the authors themselves. Both types of translators, i.e., bilingual translators who are primarily members of the source culture on the one hand and monolingual translators who are members of the target culture and translate with the help of another bilingual speaker on the other are typical as mediators from minor languages into major ones; in both cases, the outcome largely depends on the ability of the translator to produce texts which can be integrated into the target literary system.

Low-impact cultures are by definition translation cultures with a double need for translation: on the one hand, they have to produce translations from other languages if their own languages, literatures, and cultures are to flourish; on the other hand, they are often forced to provide translations from their languages on their own, simply because very few members of major cultures know a given minor language. Typically, low-impact cultures rely, to a great extent, on their own resources in their direct contacts with high-impact cultures and their languages ("self-translation" or "autonomous translation"; Cronin 2006: 40), whereas high-impact cultures typically depend on external input when importing translations of texts from low-impact cultures ("heteronymous" or "dependent translation"; Cronin 2006: 40). It is therefore quite common for a text from a low-impact culture to be first translated by the author himself / herself and then refined by a second translator, often a native speaker of the target language, who may or may not have (some) knowledge of the source language. Another practice commonly adopted in the translation of texts from low-impact cultures is to translate through an intermediary or filter language, with all the problematic consequences indirect translation implies. This was also the case with the translations of the best-seller novel Alamut mentioned above into Spanish and Portuguese, which are both based on the French translation, although this is acknowledged only in the Portuguese version (Markič 2006). In relation to the translation of texts from low-impact cultures into major languages, and in particular in relation to auto-translation, Michael Cronin asks a somewhat rhetorical question: "Does this practice create a different translation dynamic from translation between two major languages?" (Cronin 2003: 154). The experience of translating Slovene literature into Italian shows that the answer is necessarily affirmative.

\subsection{Translation strategies}

Finally, in terms of the functioning of a translated text in the target culture, it is important what strategies are employed by the translator and here the distinction between domestication and foreignization is particularly relevant. It is generally accepted that with the employment of domesticating strategies, features of the source culture are in principle wiped out and that the translated text unmistakably assumes a target-cultural identity, whereas foreignizing strategies supposedly leave more room for elements of the source culture to come to the fore. However, this is how the two 
types of strategies function at an abstract level, because the reality is far more complex. Here, too, a distinction must be made between translations of major literatures (major to major or major to minor) on the one hand and those from minor literatures to major ones on the other. If one takes, for instance, literary translations into Slovene, one can see that they easily tolerate foreignizing strategies, at least in terms of the lexical choices (such as proper names, geographical names, and other culturespecific references) and in terms of rhetorical choices, less so at the levels of morphosyntax and phraseology. As a peripheral literature which has for centuries been very active as a recipient of foreign literary texts, ${ }^{15}$ Slovene literature has been more open to new models than canonical and therefore relatively self-sufficient literatures often tend to be - although in the latter too, the translation strategies adopted vary widely so that the difference can be one of degree rather than of kind. Further, because of the relative strength of foreign influences compared to the Slovene native tradition their impact has been very great indeed.

Therefore the tendency to domestication in the translation of Slovene literature into Italian is understandable: in general, structural linguistic foreignization may demand greater skillfulness from the translator than domestication, because by transposing linguistic patterns of the source text one may easily run the risk of too literal a translation, which may in the end make the text poetically rather feeble. Also, linguistic foreignization may be rather questionable as a means of enabling the reader to gain access to the foreignness of a given source text, for it is difficult to imagine how mere fragments of different aspects of a given source language can be sensibly represented by means of another (i.e., target) language in such a way that target readers would be able to get a meaningful idea of them. Therefore, it is important that the choice of either of the two strategies is motivated by the aim which underlies a given translation project. Is the aim merely to give a foreign audience some vague informative idea of what the source literature is like or is the translation also meant to stimulate the readers to develop an interest in that literature? In other words, shall the target text be a literary translation or merely a translation of a literary text? ${ }^{16}$

In relation to the question of domesticating (fluent, invisible, assimilating, ethnocentric) and foreignizing (exoticizing) translation, Lawrence Venuti (1995: 23) observes: "The point is rather to develop a theory and practice of translation that resists dominant target-language cultural values so as to signify the linguistic and cultural difference of the foreign text," suggesting new, unexplored, and unorthodox features of the target language use and exploiting in it

“as yet unknown minor languages" [Deleuze and Guattari 1987]. The aim of minoritizing translation is "never to acquire the majority," [Deleuze and Guattari 1987] never to erect a new standard or to establish a new canon, but rather to promote cultural innovation as well as an understanding of cultural difference [...] (Venuti 1998: 11).

Venuti's proposal, which is primarily to challenge the mechanisms upon which the functioning of high-impact cultures, like the Anglo-American culture, is based, may offer very good solutions in this regard, but not all texts from all literatures can be imported into a dominant culture in such a way. For rather invisible low-impact cultures to obtain at least minimal visibility within a major culture, relative domestication appears to be a safer option, for in too foreign a context defamiliarization can hardly take place. In actual fact, the very decision to translate texts from a marginal 
literature can be considered a foreignizing and minoritizing project. ${ }^{17}$ Therefore foreignizing translations may represent a sensible option when a literature has already obtained a place in a foreign culture, when some context for its reception as a foreign literature has already been created (Ožbot 2000: 87-88) and when it is safe to depart from the domestic conceptual and textual grids of the target culture ${ }^{18}$ in the words of André Lefevere (1999).

\subsection{More on domestication and foreignization}

The concepts of domestication and foreignization are of such relevance in a discussion about translation of peripheral literatures into major literary cultures that they deserve some further attention.

As far as foreignizing translation is concerned, it is important to distinguish two projects; let us provisionally, and imprecisely, call them the passive project and the active project. The passive project consists in bringing the source culture and the source text closer to the target readers than they would typically be in the case of domesticating translation; a proposal in this direction is given, among others, by Lefevere, who suggests that we should try to understand, for example, Chinese T'ang poetry "on its own terms," and not "as if it were Imagist blank verse" (Lefevere 1999: 78). Regardless of how close a source culture and a source literature can actually be brought to target readers by means of translation, the fact remains that it is impossible for any translation as "a fact of target culture" (Toury 1995: 29) to enable target readers to have genuine access to the source culture. A translation can only be a functional substitute for a source text (i.e., it can function in place of a source text, although it has a life of its own), but can never faithfully represent it. A translation has its own identity as a target-culture text, in which the target language is necessarily the primary code, irrespective of whether the overall nature of the text is domesticating or foreignizing (Berman 1999: 34). This implies that a translation can never be more than an echo, a recalling or a reverberation of the original (Menke 2002: 83-84); what kind of echo, recalling or reverberation it will be is a function of the choices made by the translator. The active project, on the other hand, aims at using translation as an instrument by means of which the target culture itself can be made to change and by means of which its presupposed political, cultural and other values can be questioned and challenged. This has to an extent always been attempted, especially in non-canonical literatures, the development of which may often depend heavily on external stimuli. A related phenomenon is the function of translation as "an agent of regeneration in the target language" (Cronin 2003: 147) and as part of political agendas, as was, for instance, the case with the revival of several European languages in national movements from the mid nineteenth century on, including Slovene but also, for example, Czech, Norwegian, Provençal and Irish (where Cronin talks of "the revival of the Irish language as the vernacular language of the Irish people"; Cronin 1996: 153). Somewhat paradoxically perhaps, foreignizing translation - often as a project intended to change the target culture - normally presupposes an overtly domestic agenda.

The purpose of exporting a peripheral literature into a major culture, however, is usually a very different one. The goal of such an undertaking is primarily to familiarize the target audience with a hitherto unknown or hardly known literature and to make the readers aware of its communicative potential. It is normally through 
domesticating translation strategies, at least in terms of the syntactic language structure, that such aims can be achieved.

A short illustration of this point is offered by Srečko Kosovel's poem O dogmatiki (Oh, dogmatics, 2000: 210) in Italian translation by Jolka Milič ${ }^{19}$ (translated into English by the author):

\begin{tabular}{|c|c|}
\hline \multirow[b]{2}{*}{1} & O dogmatiki \\
\hline & $\begin{array}{l}\text { O dogmatiki, } \\
\text { [Oh dogmatics, }\end{array}$ \\
\hline \multirow{6}{*}{5} & $\begin{array}{l}\text { o doktrinarji, } \\
\text { [Oh doctrinaires, }\end{array}$ \\
\hline & $\begin{array}{l}\text { o čudni, prečudni kritiki, } \\
\text { [Oh weird, very weird critics, ] }\end{array}$ \\
\hline & $\begin{array}{l}\text { o vi bledi otroci razuma! } \\
\text { [Oh you pale children of reason!] }\end{array}$ \\
\hline & $\begin{array}{l}\text { A jaz krvavim } \\
\text { [But I am bleeding] }\end{array}$ \\
\hline & $\begin{array}{l}\text { sredi srca } \\
\text { [In the middle of my heart] }\end{array}$ \\
\hline & $\begin{array}{l}\text { in vem, kaj se pravi živeti } \\
\text { [And I know what it means to live] }\end{array}$ \\
\hline \multirow{4}{*}{10} & $\begin{array}{l}\text { sredi sivih cest, } \\
\text { [In the middle of grey roads, ] }\end{array}$ \\
\hline & $\begin{array}{l}\text { v praznem srcu bolest, } \\
\text { [Pain in an empty heart,] }\end{array}$ \\
\hline & $\begin{array}{l}\text { in, preden izrečeš svojo besedo, } \\
\text { [And before you utter your last word] }\end{array}$ \\
\hline & $\begin{array}{l}\text { umreti. } \\
\text { [To die.] }\end{array}$ \\
\hline
\end{tabular}

\author{
O dogmatici \\ O dogmatici, \\ [Oh dogmatics,] \\ o dottrinari, \\ [Oh doctrinaries, \\ O strani, stranissimi critici, \\ [Oh weird, very weird critics,] \\ O pallidi figli della ragione! \\ [Oh pale children of reason!] \\ Il mio cuore \\ [My heart] \\ invece sanguina, \\ [Though bleeds,] \\ conscio di quanto costi vivere \\ [Aware of what it costs to live] \\ tra strade grigie, \\ [Between grey roads, ] \\ nel cuore vuoto la pena, \\ [In the empty heart the pain,] \\ E prima ancora di proferire parola, \\ [And before uttering a word,] \\ dover morire. \\ [To have to die.]
}

(Kosovel 1972/2000: 210, translated by Jolka Milič)

The target text is clearly domesticating in nature, for it seems that the translator's intention is to convey a poetic message rather than produce a defamiliarizing text which would call the reader's attention to idiosyncrasies stemming from its having been produced on the basis of a linguistically different source text. In fact, there is nothing in the Italian version which would explicitly signal that it is a translation, and the changes in the target text which may appear dispensable from a systemic point of view seem to be there precisely to enhance its idiomaticity. Thus, for example, in line 5 an inanimate noun (cuore /heart/) is made the subject of the verb sanguinare (/to bleed/), whereas in the original the subject is jaz $(/ \mathrm{I} /)$ and srce $(/$ heart/) is part of an adverbial adjunct; in line 10 the temporal conjunction prima (/before/) is intensified by the adverb ancora; and in line 11 a deontic modal verb (dovere) is added to the lexical verb morire (/to die/) - by virtue of all these choices the text reads like a more genuinely Italian poem than it would if no such modification was made.

From among many other possible examples let us mention the translations of poems of a younger, though, compared to Kosovel, more traditionally modernist writer Miroslav Košuta (b. 1936). The following text, which is taken from his bilingual book of poems (Košuta 1999: 134-135) translated into Italian by Daria Betocchi, ${ }^{20}$ who is, like the author himself, a bilingual Slovene-Italian speaker from Trieste, 
shows again that the translator was preoccupied with making the target text highly domesticating, her choices being further constrained by the decision to preserve the rhyme (translated into English by the author):

\section{Daljava}

1 Blešči se, blešči daljava. [There shines, shines a distance.] Je morje? - Je plava. [Is it the sea? - It is blue.] [What else could it be then,] Meni tako dragega. [To me so dear.]

\author{
Lontananza \\ Brilla lontano lontano, laggiù. \\ [It shines far away, far away, down there.] \\ È il mare? - È blu. \\ [And the sea? - It is blue.] \\ Cos'altro vuoi dunque che sia \\ [What else would you want it to be] \\ di così caro all'anima mia. \\ [Of what to my soul is so dear.]
}

(Košuta 1999: 134, translated by Daria Betocchi 1999: 135)

Here again, it is clear that target-language idiomaticity is considered superior to any attempt to make the expression of the source text transparent in the translation. So, for instance, in the first line of the target text the adverb lontano (/far/) is repeated rather than the verb form, as is the case in the source text (blešči se, $3^{\text {rd }}$ person of bleščati se /to shine/). Also, the somewhat pleonastic laggiù (/down there/) is placed at the end of the line in order to produce a rhyme with blu (/blue/) in the following line. Then, in line 3 a second-person verb form vuoi from volere (/to wish/) is used, introducing a supposed addressee, whereas the source text does not contain an overt apostrophe. Finally, in line 4 instead of a form of $1^{\text {st }}$-person pronoun (meni /to me/, dative of jaz) there is the phrase anima mia (/my soul/), probably for reasons of rhyme and meter. Like the previous translation, this one also appears as a genuine Italian text which bears no trace of its foreign origin.

\section{Conclusion}

The poems discussed are, of course, only two decontextualized, though paradigmatic, examples of the kind of operation that may be necessary if a text is to function successfully in a target situation. Similar domesticating translation choices could be adduced from many other Slovene literary texts in Italian translation (Ožbot 2000), and likewise from texts concerning other language pairs. No doubt, the importance of the domestication strategy is difficult to assess, but it certainly does play a major role, together with other decisions at the textual and extra-textual level taken by the agents involved in the translation process, as was attempted to be shown through a discussion of the postulated four factors.

Trying to sum up the fundamental features of the exportation of Slovene literature, via translation, into Italian, the following observations can be made. Although the Slovene authors who have managed to succeed in an Italian cultural context do not share a common denominator which could explain the mechanisms underlying their positive reception in the target culture, one thing is obvious: their texts have a potential which has been used adroitly by translators, editors and, publishers, and by virtue of which these texts could be integrated into the target literary system. No matter what drawbacks such an overall target-oriented approach may entail, it offers a way to avoid the production of texts which are unconvincing in literary terms in 
the target language. And this is, in fact, a principal aim which literatures, authors and translators have when setting off on a journey away from home.

\section{NOTES}

1. See also the following statement by Pascale Casanova (2004: 250): “The mutual interest of writers from small countries in each other is as much literary as it is directly political; or rather, their readings of one another are so many implicit affirmations of a structural similarity between the literature and politics of small countries."

2. In the Italian provinces of Trieste (Trst), Gorizia (Gorica) and Udine (Viden), there is a Slovene minority of about 70,000-80,000 people, who are bilingual speakers of Slovene and Italian. Some important Slovene writers are also members of this community.

3. Among the classics which have been translated several times there are also the Romantic France Prešeren and the Modernist Srečko Kosovel. Among the poets of local significance, the most successful has perhaps been Ljubka Šorli (1910-1993), a woman poet from Gorizia, whose work is familiar to both Slovene and Italian readers from the region (see Jan 2001a: 89-97).

4. Given the proximity of the two countries, one might expect greater interest from both directions. A similar case is reported by Wehle (1996: 162-164), who analyzes the presence of French literary texts on the German market and considers the prevalence of the American culture to play an important role in shaping the situation.

5. After its second edition appeared early in 2008, the translation of Pahor's Nekropola has become a national best-seller. Interestingly, the author's critical acclaim in Italy, where he has spent nearly all his life, only came after his success in other countries. It is likely that the Italian interest in his work has been mediated rather than direct; Pahor's success abroad may have significantly encouraged the translation of his texts at home.

6. CANKAR, Ivan (1930): The bailiff Jernej and his rights. (Translated in English by Sidonie Yeras and Sewell H. C. Grant) London: John Rodker (first publication in this language). Cankar, Ivan (1930/1976): Il servo Jernej e il suo diritto. (Translated in Italian by Arnaldo Bressan) Milano: Feltrinelli. [Orig.: CANKAR, Ivan (1938/1992): Hlapec Jernej in njegova pravica. Ljubljana: Mladinska kniga.]

7. Bartol, Vladimir (1938/1993): Alamut. (Translated in Italian by Arnaldo Bressan) Milano: Rizzoli. [Orig.: BARTOL, Vladimir (1938/1988): Alamut. Ljubljana: Mladinska knjiga.]

BARTol, Vladimir (1938/1998): Alamut. (Translated in French by Claude Vincenot) Paris: Phébus. BARTOL, Vladimir (1938/1989): Alamut. (Translated in Spanish by Mauricio WACQuez) Barcelona: Muchnik Editores.

Bartol, Vladimir (1938/2004): Alamut. (Translated in Portuguese by Carlos Correia Monteiro DE Oliveira) Lisboa: Ulisseia.

BARTol, Vladimir (1938/2004): Alamut. (Translated in English by Michael Biggins) Seattle: Scala House Press.

8. PAHOR, Boris (1967/1995): Pilgrim among the shadows. (Translated in English by Michael Biggins) New York/San Diego/London: Harcourt Brace \& Co. PAHoR, Boris (1967/1997): Necropoli. (Translated in Italian by Ezio MarTin) San Canzian d'Isonzo: Edizioni del consorzio culturale del Monfalconese. New edition in 2008, Roma: Fazi Editore. [Orig.: PAHor, Boris (1967): Nekropola. Maribor/Trst: Obzorja/Založništvo tržaškega tiska.]

9. Kovačič Lojze (1983-1985/2004): The Newcomers. (Translated by Klaus Detlef Olof) Klagenfurt: Drava. [Orig.: Kovačıč, Lojze (1983-1985/2004): Prišleki. 3 vols. Ljubljana: Slovenska matica.]

10. The most recent collection is: ZLOBEC, Ciril (2004) Ljubezen - svetlo sonce in temà; Amore - sole nero e oro solare. (Translated by Luciano Luisi, Grytzko Mascioni, and Giacomo ScotTI) Udine: Campanotto Editore. The most representative one is: Zlobec, Ciril (1991): La mia breve eternità: Antologia personale 1950-1990. Roma: Bulzoni.

11. The first collection was: KosoveL, Srečko (1964-1977/1972): Poesie di velluto e integrali. (Translated by Jolka MiLIČ) Trieste: L’Asterisco editore. The two most recent ones are: Kosovel, Srečko (2002): Kons. (Translated by Jolka Misıč) Trieste: Ramo d'oro/Tržaška knjigarna - Libreria triestina; Kosovel, Srečko (2002): Il mio canto/Moja pesem. (Translated by Jolka MiLIČ) Trieste: Ramo d’oro/ Tržaška knjigarna - Libreria triestina.

12. Kosovel's poetry has also been widely translated into other languages, including English, German, and French. The most recent collection of his poems in English is: Kosovel, Srečko (1964- 
1977/2008): The Golden Boat: Selected Poems. (Translated by David Brooks and Bert Pribac) Cambridge: Salt Publishing.

13. To some degree, the most recent bilingual Slovene-Italian edition of Prešeren's poetry bodes well: the translations - made by Giorgio Depangher in collaboration with Marija Pirjevec - and the introduction - written by the latter - do take into account the tastes and the cultural horizons of the target readers. On the other hand, many culture-specific elements of the original poems, including historical and literary references, are retained without being explained (see: PrešEREN, France (1998): Poesie/Pesmi. Kranj/Trieste: Mestna občina Kranj/EST).

14. On the strategies employed by different translators of Prešeren's poetry into Italian see Pirjevec (1997); a brief critical survey of Italian translations of Prešeren's poetry is offered in Pirjevec (2001).

15. In actual fact, The Freising Monuments (Brižinski spomeniki), the earliest Slovene texts (dating from the $10^{\text {th }}$ to $11^{\text {th }}$ century), also contain translations from Latin and German (two confession formulas and a sermon on sin and repentance). Later too, translation provided vital impetus for the development of the Slovene language and literature, especially in the Reformation period, with the first Slovene version of the Bible (1584).

16. Here literariness is considered a feature of the text resulting from the readers perceiving its function as literary; and what will be perceived to have a literary function is largely determined by the linguistic and literary tradition of the target literature. This implies that for a translation to be considered a literary text, it has to be formed in such a way as to fit into the network of the target literary system, i.e., it has to correspond, however marginally, to the criteria of literariness set in the target culture (see Aviram 1998: 101-102; Ožbot 2001a: 390).

17. See Venuti (1998: 10): "To shake the regime of English, a translator must be strategic both in selecting foreign texts and in developing discourses to translate them."

18. An interesting parallelism of some sort can be gathered from Cronin's presentation of the Irish situation at the turn of the $19^{\text {th }}$ and $20^{\text {th }}$ centuries. At the time, some writers felt an urge for foreignizing translation from Irish into English in order "to convey the excitement and the beauty of the source language in the target language" (Cronin 1996: 141). J. M. Synge, a principal actor in the project, considered it feasible, because "the linguistic atmosphere of Ireland has become definitely English enough, for the first time, to allow work to be done in English that is perfectly Irish in essence"' (Cronin 1996: 141, italics from the author).

19. Kosovel, Srečko (2000): Ves svet je kakor: Pesmi, integrali./Tutto il mondo è come: Poesie, integrali. (Translated by Jolka MiLıč) Sežana: Občina/Comune.

20. Košuta, Miroslav (1999): Memoria del corpo assente./Spomin odsotnega telesa. (Translated by Daria Betocchi) Trieste: ZTT EST.

\section{REFERENCES}

Aviram, Amittai F. (1998): Literariness, Markedness, and Surprise in Poetry. In: Carol MyersScotton, ed. Codes and Consequences: Choosing Linguistic Varieties. New York: Oxford University Press, 101-123.

Benjamin, Andrew (2002): The absolute as translatability. Working through Walter Benjamin on language. In: Beatrice Hansen and Andrew Benjamin, eds. Walter Benjamin and Romanticism. New York: Continuum, 109-122.

Berman, Antoine (1999): La traduction et la lettre ou l'auberge du lointain. Paris: Seuil.

BreCELJ, Marijan (1965): Onorate l'altissimo poeta: ob sedemstoletnici Dantejevega rojstva 12651965. Nova Gorica: Goriška knjižnica. [Italian version: Onorate l'altissimo poeta: nel settimo centenario della nascita di Dante: 1265-1965. Bibliografia dantesca slovena. Gorizia: /s.n./].

BreCELJ, Marijan (2000): Štiri stoletja in pol pevajanja italijanskih besedil v slovenščino 15502000: Biliografsko gradivo. Nova Gorica: Goriška knjižnica Franceta Bevka.

Casanova, Pascale (2004): The World Republic of Letters. (Translated by M. B. DeBevoise) Cambridge, Mass: Harvard University Press.

Cronin, Michael (1996): Translating Ireland: Translating Languages, Cultures. Cork: Cork University Press.

Cronin, Michael (2003): Translation and Globalization. London: Routledge.

Cronin, Michael (2006): Translation and Identity. London: Routledge. 
JAN, Zoltan (2001a): Cankar, Kosovel, Zlobec in Ljubka Šorli pri Italijanih. Ljubljana: Rokus. JAN, Zoltan (2001b): Poznavanje slovenske književnosti v Italiji po letu 1945. Ljubljana: Rokus. JAN, Zoltan (2004): Srečko Kosovel pri Italijanih. Primorska srečanja. 273:16-23.

Lefevere, André (1999): Composing the other. In: Susan Bassnett and Harish Trivedi, eds. Post-colonial Translation. London: Routledge, 75-94.

MARKIČ, Jasmina (2006): Alamutova popotovanja po Iberskem polotoku. In: Martina OžBot, ed. Prevajanje besedil iz prve polovice 20. stoletja: 31. zbornik Društva slovenskih književnih prevajalcev/Translation of texts from the first half of $20^{\text {th }}$ century: Proceedings of the Association of Slovene Literary Translators, Volume 31. Ljubljana: Društvo slovenskih književnih prevajalcev, 124-137.

Menke, Bettine (2002): 'However one calls into the forest...' Echoes of translation. (Translated by Robert J. Kiss) In: Beatrice Hansen and Andrew Benjamin, eds. Walter Benjamin and Romanticism. New York: Continuum, 83-97.

Novak, Boris A. (2001): Verzifikacijski problemi prevajanja Prešerna v angleščino in francoščino. In: Martina Оžвот, ed. Prevajanje Prešerna - Prevajanje pravljic: 26. zbornik Društva slovenskih književnih prevajalcev/Translation of Prešeren - Translation of Fairy Tales: Proceedings of the Association of Slovene Literary Translators, Volume 26. Ljubljana: Društvo slovenskih književnih prevajalcev, 19-30.

Оžвот, Martina (2000): Slovene Literature in Italian Translation: Facts, fiction and beyond. In: Meta Grosman, Mira Kadric, Irena Kovačič, et al., eds. Translation into non-mother tongues: in professional practice and training. Tübingen: Stauffenburg, 81-89.

Оžвот, Martina (2001a): Problemi posredovanja slovenskih literarnih besedil v tuje kulture. In: Martina Оžвот, ed. Prevajanje Prešerna - Prevajanje pravljic: 26. zbornik Društva slovenskih književnih prevajalcev/Translation of Prešeren - Translation of Fairy Tales: Proceedings of the Association of Slovene Literary Translators, Volume 26. Ljubljana: Društvo slovenskih književnih prevajalcev, 388-394.

Оžвот, Martina (2001b): Some Remarks on Asymmetrical Cultural Transfer: The Case of Slovenian Literature for Italian Readers. In: Eteiro Pajares, Raquel Merino, Jesús, SANTAMARÍA, eds. Transvases culturales: literatura, cine, traducción. Vitoria: Servicio Editorial de la Universidad del País Vasco, 297-303.

PirJevec, Marija (1997): Troje strategij pri prevajanju Prešernovega soneta v italijanščino. In: Boris Paternu and Franc Jakopin, eds. Sonet in sonetni venec. Ljubljana: Filozofska fakulteta, 329-335.

PirJevec, Marija (2001): Prodor prvega slovenskega klasika v italijanski svet. In: Martina Оžвot, ed. Prevajanje Prešerna - Prevajanje pravljic: 26. zbornik Društva slovenskih književnih prevajalcev/Translation of Prešeren - Translation of Fairy Tales: Proceedings of the Association of Slovene Literary Translators, Volume 26. Ljubljana: Društvo slovenskih književnih prevajalcev, 119-124.

ŠKERLJ, Stanko and RAKAR, Atilij (1965): Pubblicazioni dantesche in lingua slovena (1922-1964). In: Vittore BrancA and Ettore CACCIA, eds. Dante nel mondo. Firenze: Olschki, 313-318.

Toury, Gideon (1995): Descriptive Translation Studies and Beyond. Amsterdam: John Benjamins. Venuti, Lawrence (1995): The Translator's Invisibility: A History of Translation. London: Routledge. Venuti, Lawrence (1998): Scandals of Translation. London: Routledge.

Wehle, Winfried (1996): Das langsame Abschied vom nahen Fremden. In: Fritz Nies (in collaboration with Bernd KORTLÄNDER), ed. Literaturimport und Literaturkritik: das Beispiel Frankreich. Tübingen: Narr, 157-167. 